\title{
Being clean is being strong Policing cleanliness and gay vices in the Netherlands Indies in the 1930s
}

\author{
Marieke Bloembergen
}

Cleanliness and colonial policing are connected in an important way. This seems to be the message of some advertisements in the Netherlands Indies colonial police journals around 1940, and they clearly addressed the colonial police. One promoting Purol (Figure 1), for example, pointed to the importance of clean feet and clean socks for policing; Lifebuoy soap advertisements stressed the importance of fresh body odour in order to stay firm (Figure 2), and one even promised protection against German measles (rode hond, literally 'red dog') (Figure 3). This last one also seemed to celebrate the sheer bodily pleasure of showing masculine beauty. These ads caught my attention during my research on the dirty work of empire - or colonial policing in the Netherlands Indies. ${ }^{1}$ They all seem to transmit the important message that being clean is being strong. Looking at these pictures from a present-day point of view and with hindsight, they also provide an awkward comment on the peculiar episode of vice policing that will be discussed in this chapter: the pursuit of homosexuals in the Netherlands Indies colonial society during 1938 and 1939. For, might the last advertisement possibly be an appeal to gay eroticism in the masculine organization of the colonial police?

The so-called 'vice scandal' - as the mass arrests of homosexuals in the Netherlands Indies in 1938-1939 came to be known - has been investigated from the perspective of the victims and (European centred) homosexual subcultures. ${ }^{2}$ Here I focus especially on the role of the police in this remarkable project of moral cleaning, to come to a further understanding of the problem of colonial policing in the late colonial state.

1 Bloembergen 2007, 2009. The present article is a slight revision of a case study in Bloembergen 2009:299-332.

2 It is strange that this well-known vice scandal has not yet been used as an entrance for the still to be written study of masculinity and homosexuality in the Netherlands Indies. On the case itself, see Kerkhof 1982, 1992. See also Koenders 1996; Aldrich 2003. 


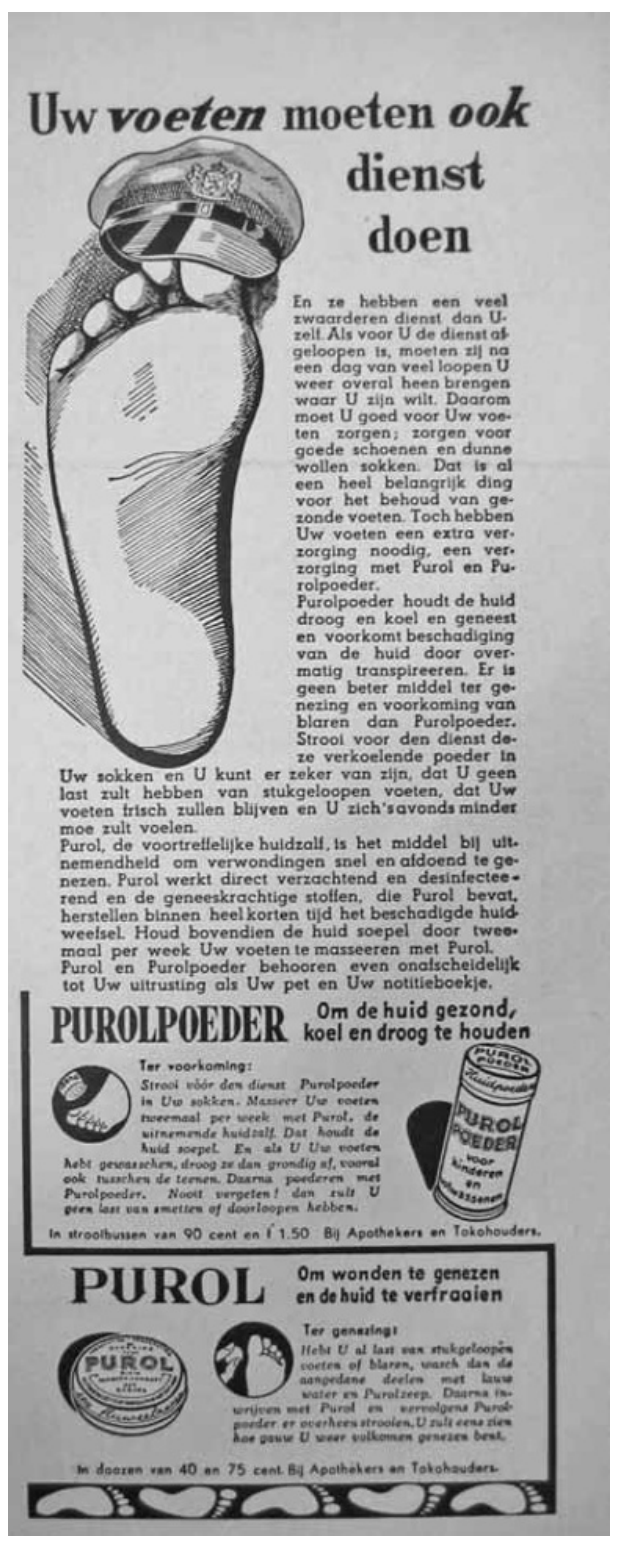

Figure 1. Your feet have to serve as well [...] Purol powder. To keep the skin clean, cool and dry.' Purol advertisement, published in De Politie, 1941. 


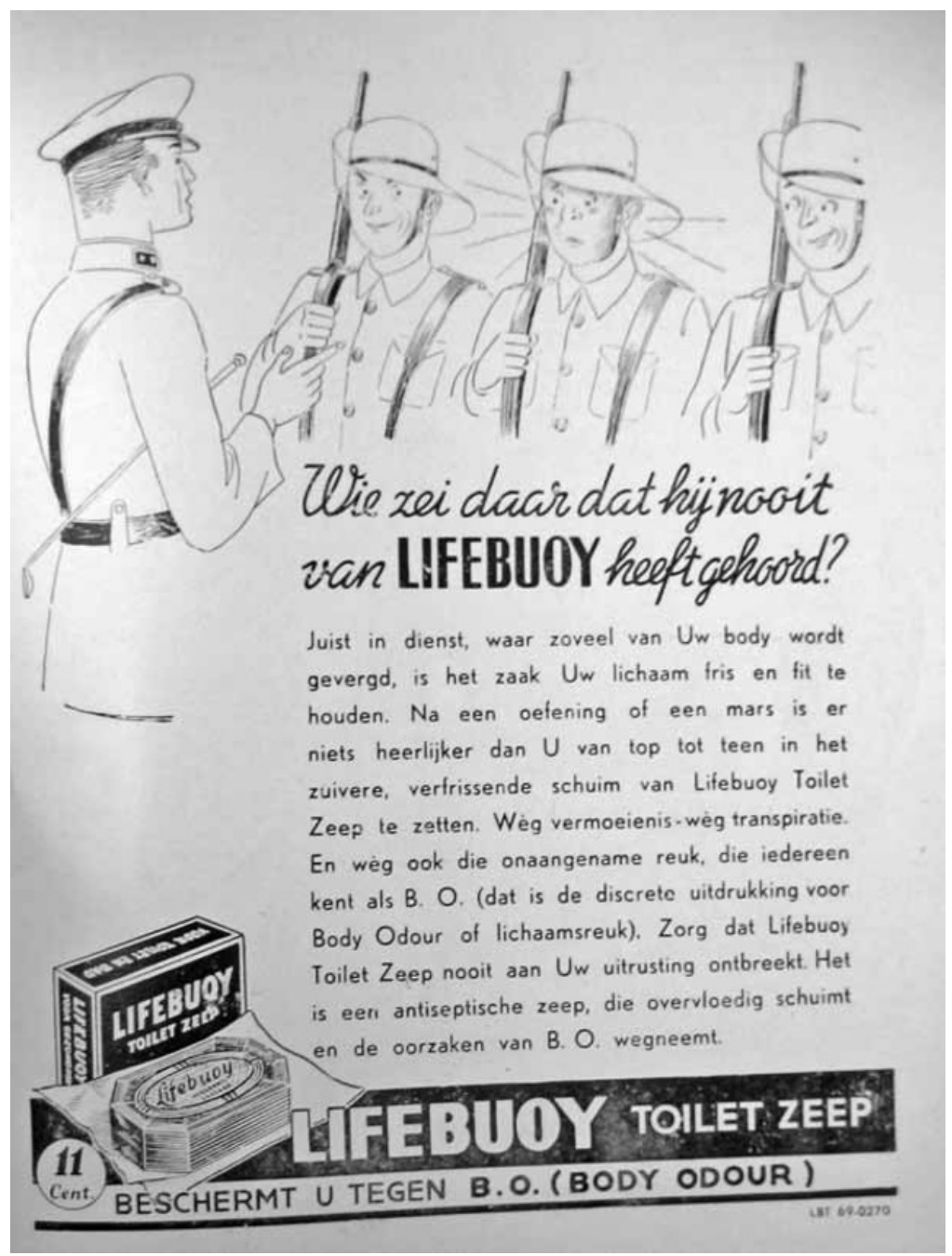

Figure 2. 'Who said that he had never heard of LIFEBUOY? Especially in the service, when so much is asked of your body, it is important to remain fresh and fit.' Lifebuoy advertisement, published in De Politie, 1941. 


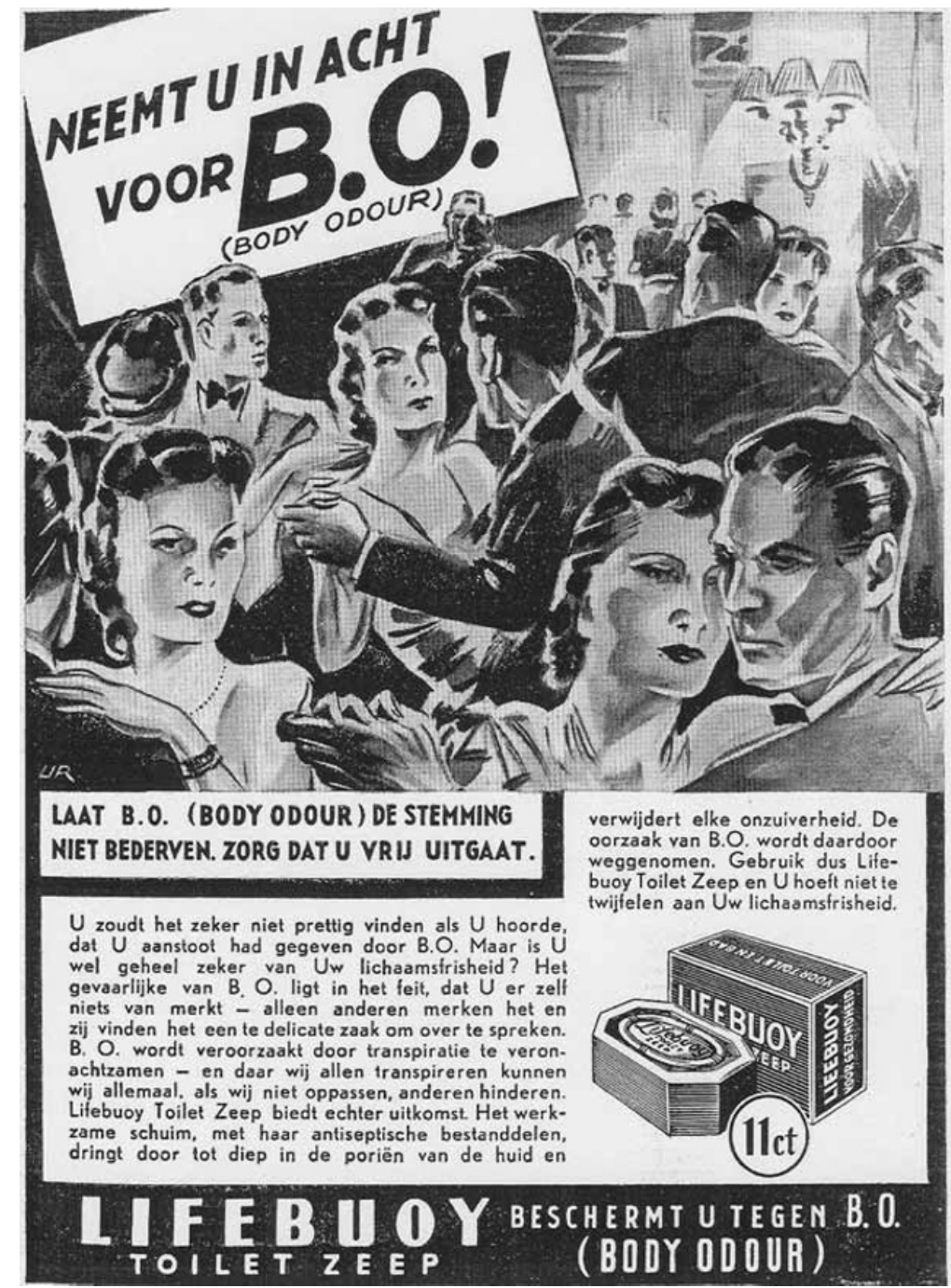

Figure 3. 'LIFEBUOY not only refreshes you, but it also prevents you from B.O. (Body Odour).' Lifebuoy advertisement, published in De Politie, 1937. 
Between December 1938 and May 1939, the colonial police arrested around 225 men throughout the Netherlands Indies, mostly Europeans, many of whom had good social standing. A number of them were even high officials of the Netherlands Indies colonial administration. These men were suspected of having had sexual relationships with persons of the same sex under the age of 21, which was against the law in the Netherlands Indies (as it was in the Netherlands) in accordance with Article 292 of the Indies Criminal Law. 171 of them were found guilty. The Netherlands Indies newspapers followed this remarkable mass arrest of homosexuals - which had never happened before on such a scale in the Netherlands Indies - with great interest and referred to it as 'de grote schoonmaak' (the great spring-cleaning), 'zedenschoonmaak' (moral cleaning) or 'het reinigingsproces' (the cleansing process). At the same time they introduced the suspects of homosexual sex - at first by full name, later on by initials, town, and occupation - as representatives of a 'poel der verwording' (cesspool of vice) and 'vies gedoe' (dirty stuff). ${ }^{3}$ This, in a nutshell, was the 'vice scandal'.

What can this explosion of 'moral cleansing' tell us about the functioning of the colonial police and the late colonial state? Apparently, this hunt was motivated by standardized conceptions of 'clean' and 'cleaning'. In the process of hunting down suspects, the police may have enhanced these notions, and contributed to the stigmatization of homosexuality in the colony in general, and the individual victims in particular. At first sight, these police raids on homosexuals were part and parcel of the colonial state's multidimensional politics of hygiene and civilization. ${ }^{4}$ But, when we consider the colonial state's previous policy towards sexual offences or towards homosexuality, and the regular occupations of vice squads in the Netherlands Indies, the aim of this moral cleansing is not so obvious. The stated aim of the police raids in 1938-1939 was to only track down those homosexuals who had committed paedophilia (the minority age being until 21 ), which was a violation of article 292 of the Indies' penal code. It was, however, obvious that police investigation methods were directed against homosexuals in

3 In the period 27 December 1938 until 16 May 1939, the Bataviaasch Nieuwsblad used 26 times 'Het reinigingsproces' (the cleansing process) as the heading for news-articles on tracing and prosecuting homosexuals, once, on 10 March, 'schoonmaak' (cleaning), and within that same article 'spring cleaning'. For 'poel der verwording', Nieuws van den Dag voor Nederlandsch-Indië, 27-12-1938 and 'vies gedoe', Indische Courant, 9-1-1939, both quoted in Kerkhof 1982:61, 69.

4 See, among others, Abalahin 2003. 
general. The mass arrests of homosexuals were therefore the more remarkable since, until then, the existence of homosexuality in the Netherlands Indies was well known, and generally tolerated. More importantly, homosexuality in itself was not against the law in the Netherlands Indies (nor in the Netherlands) (Kerkhof 1982:25-8).

The history of homosexuality and European and indigenous perceptions of homosexuality in the Netherlands Indies still need to be investigated and written. But it may be inferred that, along the lines of imported Christian notions, the majority of the European community in colonial society regarded homosexuals as unnatural, abnormal, or unclean. Moreover, a few critical Indonesian reactions to the 'vice scandal' indicate that at least in the eyes of some Indonesian spokesmen - representatives of the modern educated Indonesian elite homosexuality was a disease, even a danger. ${ }^{5}$ But these comments, like the upheaval in the European newspapers in 1938 and 1939, were made in hindsight. One of the Indonesian sources I am referring to, Bahaja homo-sexualiteit dan bagaimana membasminja (The danger of homosexuality and the ways to overcome it), by the Minangkabau author Maisir Thaib - a warning guide for parents of boarding school students in West Sumatra - implies indirectly that until then, also within indigenous societies the practice of intimate boy friendships was at least tolerated. In short, it seems that until the vice scandal of 1938, homosexuality was not an official public problem.

The moral cleansing forces of the colonial state, police and private organizations (European and indigenous associations) were directed against prostitution and traffic in women and children. It was only during the 'vice scandal' that these forces also turned against homosexuality as representing a general offence against public decency and a crime. How can this sudden apparent need for moral cleansing - within the white European colonialist group - be explained? And how did it fit within the program of the colonial police, and their modern colonial vice squads?

POLICING COLONIAL CLEANLINESS AND THE PROBLEM OF CIVILIZATION

The modern colonial police force, set up in the first two decades of the twentieth century, was the face of the colonial state. It was in the interest of this state, if it wanted to be civilized and mod-

5 Thaib 1939. On the context and the message of this book, see Hadler 2008. See also the reaction to the vice scandal of the Indonesian nationalist Thamrin in the Volksraad (Advisory Council) below. 
ern, to have an effective and professional police force that could ensure public safety and enforce (political) order, while at the same time performing in an emphatically civilized way. By organizing a civilized police force that would guarantee society's need for safety, the colonial government ideally could acquire the cooperation and consent of its subjects. Moreover, through modern policing, civilization, cleanliness, decency, and hygiene could be assured - all, of course, according to an ideal of modern European standards. This could help prevent infectious diseases and maintain vigilance, and also mark a civilized state.

Fear and concern, control and the urge to 'civilize', were leading motives behind three important police reforms that the colonial government implemented in the first two decades of the twentieth century. This resulted in a more or less professional police force that consisted of the old bestuurspolitie (Administrative Police, dating from the nineteenth century), the modern city police (created in 1911-1914), the veldpolitie (Field Police: a mobile, well-armed and barracked police for security surveillance in rural areas, created in 1918-1920), and, mainly for political control, the gewestelijke recherche (Regional Investigation Department). At the central level, the Attorney General controlled this force; the Director of Interior Administration was in charge of management. At the local level the highest European administrators of the Binnenlands Bestuur (Interior Administration), or the Residents, headed the police force in their own provinces. This colonial police force was almost entirely staffed by Indonesian recruits. In the 1930s, 96 per cent of the police, out of a force of 34,000, was Indonesian. Typical for the colonial hierarchy - in which not only race, but also class mattered - only a few of them, members of the Indonesian elite, got access to the higher ranks, especially in the 1930s.

This modern colonial police force was organized both as a tool for political control and as a civil security tool - at least as a more civilized tool than the army. Where the army ensured colonial authority by the sheer presence of its force and the supremacy of its violence, the 'modern' colonial police were instructed and trained to act professionally - in a strong, constrained, sedate way, and to postpone violence as long as possible while dealing with any public security problem. ${ }^{6}$ Also, they were meant as a tool of 'civilization' to

6 For a first code for violence restriction for the police in the Netherlands Indies, see 'Voorloopig reglement van tucht voor het personeel der algemeene politie in Nederlands-Indië', in De Nederlandsch-Indische Politiegids, January 1917, Article 2.13. Like its following revisions, this article was open for interpretation. See also the handbook used at the police academy in Sukabumi by Dekker and Tacoma (1938). 
bring order, safety, cleanliness, and decency - into colonial society. This idea became part of the self-image of the policemen who were trained at the police academy in Sukabumi, which was set up in 1914, and opened for almost all ranks at the beginning of the $1920 \mathrm{~s}^{7} \mathrm{~A}$ police handbook of the 1930s opened with the government policy, formulated as a defence against criticism and police violence, that it aimed for a force of 'men of high principles of life, strong moral and character traits' - in short, to be strong (Dekker en Tacoma 1938).

How the modern colonial police imagined their task is well illustrated by the frontispiece of De Politie, the journal of the Association for Inspectors and Head-Inspectors of Police in the Netherlands Indies (Figure 4). This was one of four police associations, all set up at the end of the 1910s, beginning of the 1920s, which reflected the striving for police professionalization and civilization from within the police force. The frontispiece of De Politie showed a fit Roman soldier, armed with the sword of order and the torch of enlightenment, who guarantees law and order, neatness and civilization. Although the soldier became more muscular over the years - appealing to strong masculine fascist art in the 1930s - the content of this image never changed (Figure 5). This desired image of 'civilized police' had two sides: police that in a firm, upright and effective way provide the social need for safety, and police as a tool of the colonial forces of civilization: oom agent (Uncle) in the desa (village), who reports infectious diseases, and who ensures that everyone keeps their yards neat and tidy, and behaves well.

The image of civilized police and the idea of civilization and neatness through policing seemed to become more important in the 1930s. With further development of Indonesian nationalism and fiercer political policing, it became harder for the colonial authorities to ignore opposition to colonial rule. After the violent repression of the communist revolt of 1926-1927 (in which a large number of Muslims participated), mass arrests and the internment of around 1300 alleged communists without trial, the colonial government subsequently refined and extended the organization of political policing and enlarged the police force in general (Bloembergen 2006, 2009:247-97; Poeze 1994). The international economic crisis, which forced the government to cut down policing expenses, did not hamper the artificial image of rust en orde (law and order) or

7 The programme at the police academy was twofold: on the one hand recruits were trained in semi-military discipline, the use of arms (rifles, sabres and pistols) and physical exercises, and on how to recognize a 'communist conspiracy'. This programme reflected the needs of a police state-in-progress; on the other hand, recruits were educated in the principles of a constitutional state, criminal law and justice, and methods and rules of civilized modern policing - including restrictions on police power, and instructions on the use of force (Bloembergen 2009:203-46). 


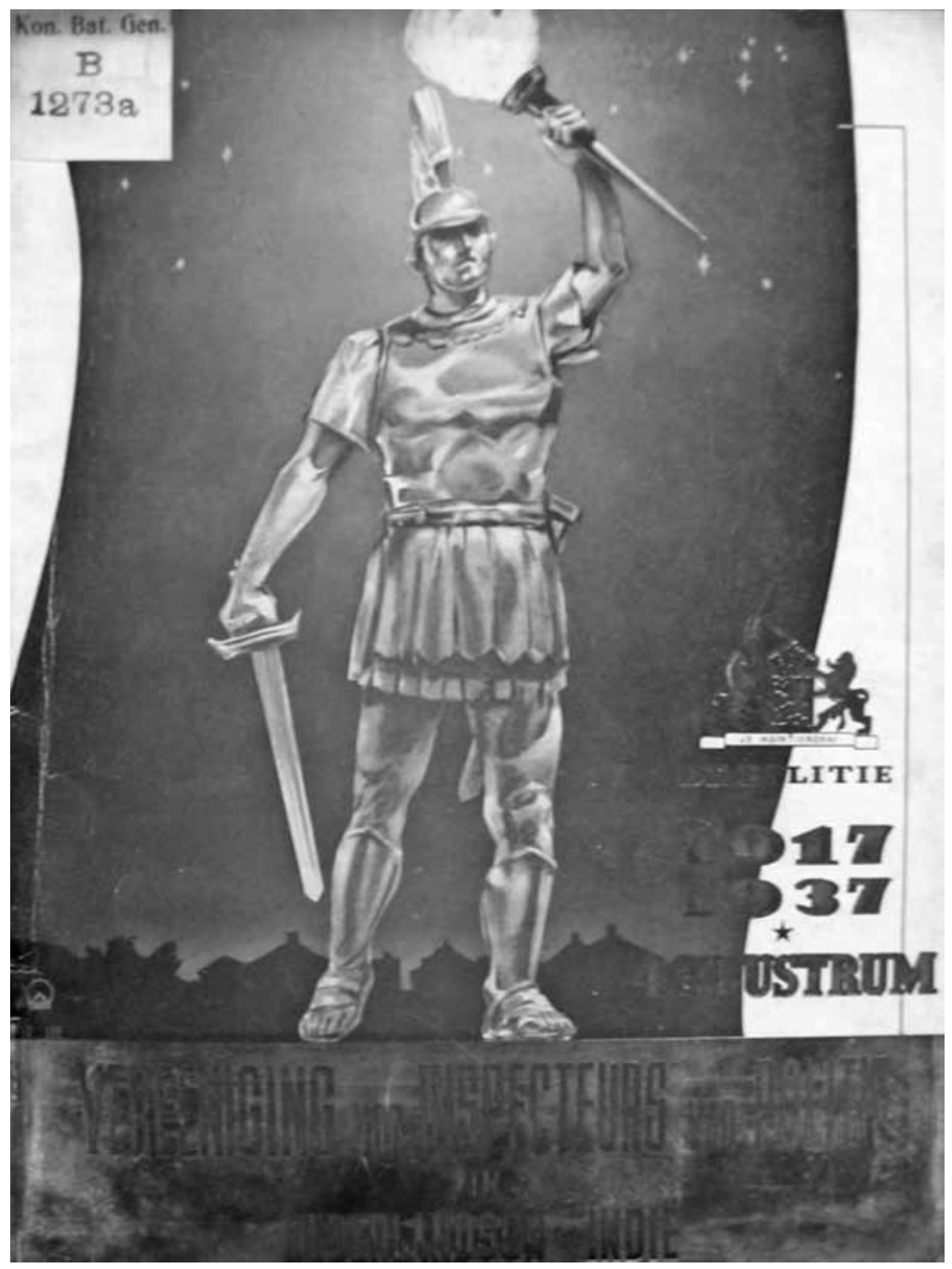

Figure 4. Frontispiece of De Politie, 1937 


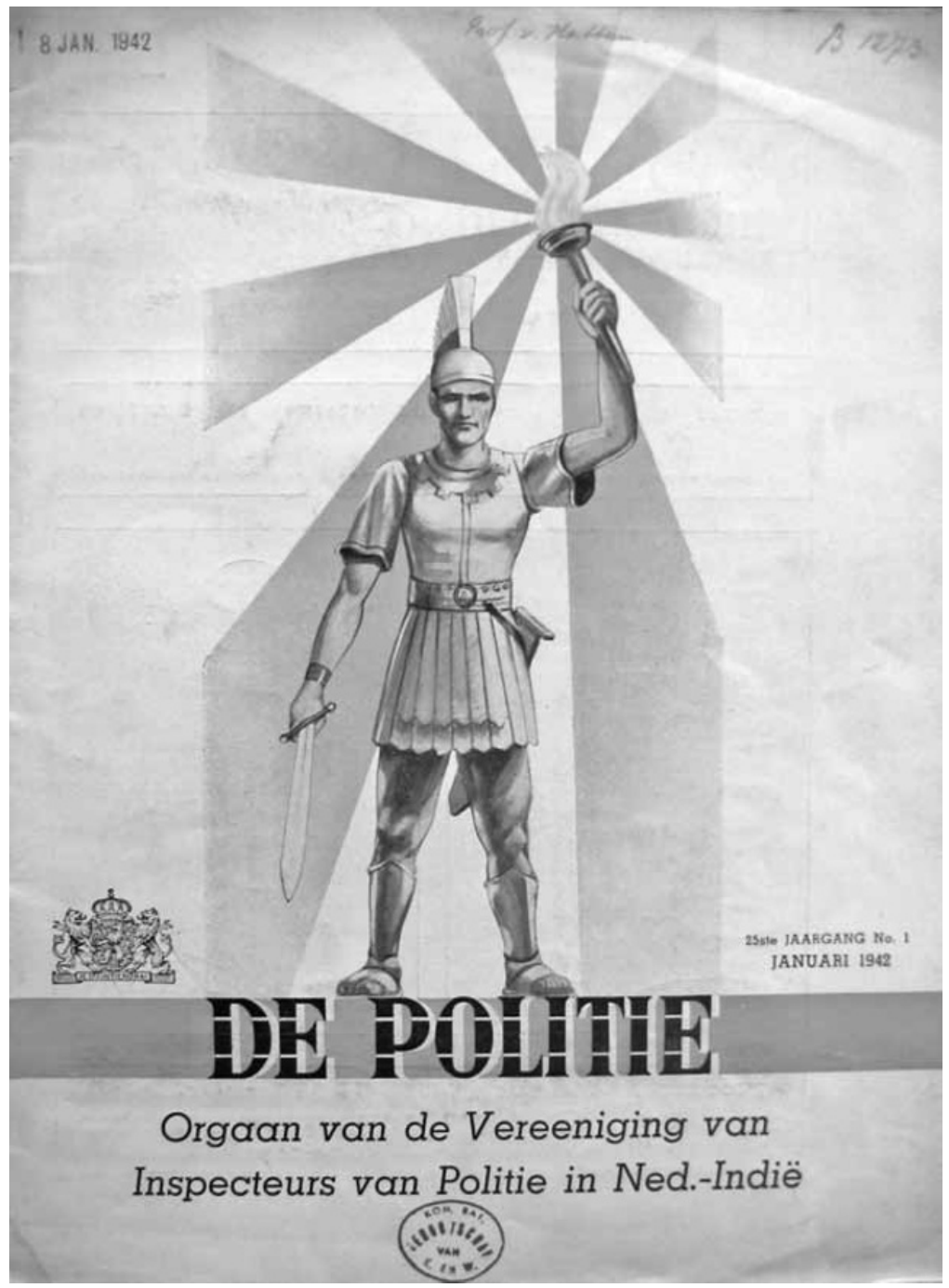

Figure 5. Frontispiece of De Politie, 1942 
zaman normal (normal times) as the 1930s have been characterized. The threat of war in Europe and Asia, however, cast a dark shadow over this false image of peacefulness and security. Meanwhile, the police, more visible because of the extension of political policing, and being watched while watching, had become the standard for the quality of colonial government (Idenburg 1961:143).

Against this background, moral policing could become an important assignment of the modern colonial police, even more important than formerly. Modern police vice squads could prove the 'civilized' intentions of this repressive colonial state. This was also how some members of the new generation of modern educated police trainees from the police academy in Sukabumi, working for the city police forces in Java's main cities, Surabaya, Semarang and Batavia, saw their task.

\section{POLICING CLEANLINESS AND VICES}

Surveillance of cleanliness and public decency became a formal task of policing in colonial administrative towns in the Netherlands Indies from the last quarter of the nineteenth century, and remained so for the modern colonial police force operating in the 1920s and the 1930s. This task was a means to colonial civilization, public hygiene, order and - ideally, from the perspective of colonial government - control.

With regard to the policing of cleanliness and zedelijkheid (public decency), and as a proof of their modernity, the new city police force in the main cities developed special vice squads, part of the city police's criminal investigation departments. ${ }^{8}$ The initiators, for example in Surabaya, were intermediate ranking European police officers who considered public decency an important and modern good, and who thereby identified with the icon of their association's journal, the Roman soldier - not only because of his sword, but also because of his torch of enlightenment. Not only the intermediate ranks, but also the highest rank in the modern police force identified and associated with the colonial forces of civilization at least in the main cities (Zedenpolitie Amsterdam 1925; Zedenpolitie Batavia 1925, 1926). The chief superintendents of the city police forces in Batavia, Semarang and Surabaya all had seats on the directory boards of a number of private 'civilizing' institutions, such as

8 On the characteristics and early practice of the modern city police forces, see Bloembergen 2007. 
Pro Juventute (For the Youth), the Association for Hygienic Education, or the Society for the Protection of Animals.

In the 1920s and 1930s the fight against prostitution and the trade in women and children became the aim of an international purity crusade. Different institutions in the Netherlands Indies got involved in this fight as well. In that regard, the police and/or their special vice squads had to deal with the Regeeringsbureau voor de Bestrijding van den Handel in Vrouwen en Meisjes en dien van Ontuchtige Uitgaven (Governmental Office for the Fight against Trade in Women and Girls and Indecent Publications), which the Government had set up in 1913. There were also all sorts of private associations, European and indigenous engaging in this fight, such as the already mentioned Pro Juventute and the Perkoempoelan Pembasmian Perdagangan Perempoean dan Anak-Anak (Association for the Suppression of Trade in Women and Children). ${ }^{9}$ These 'purifying forces' concentrated primarily on prostitution and traffic in women and girls. Street prostitution of boys, apparently, was not their concern, as long as they were not European, as we shall see later. ${ }^{10}$

Homosexual sexual offences in general did not get special attention, as can be deduced indirectly from the available criminal statistics - however unreliable these might be. ${ }^{11}$ This also appears from the content of the journals of the four police associations. These showed no interest in homosexual vices, with one exception in 1936, which became meaningful, as we shall see below. This lack of interest is not surprising, since homosexuality in itself was not an offence, only some acts were. Apparently it was male sexual abuse of women and girls, rather than of boys, that had priority. ${ }^{12}$ It was only after the vice scandal, that several medical specialists, who

9 For more examples, see Abalahin 2003. On Pro Juventute, and attitudes of the colonial state and colonial society towards youth delinquency, and youth re-education, see Dirks 2011.

10 Street boys and young male vagabonds who, via the police, ended up in private and state sponsored juvenile re-education facilities mainly did so because of petty crime and vagrancy. These juvenile re-education facilities were primarily male oriented. Personal communication Annelieke Dirks, 9-6-2008, PhD thesis 'Juvenile delinquency, colonial civil society and the late colonial state in the Netherlands Indies, circa 1880-1942'. (Leiden University, 2011). The vice scandal of 1939 apparently made a difference to this policy, as we shall see below.

11 From the Criminal Statistics based on material provided by the European Law Courts before 1935, it is hard to determine if those men, who were prosecuted for 'general' sexual vices, committed the crime as defined by Article 292. Kerkhof counted an average of 10 men yearly. Only since 1935 the criminal statistics distinguished the category of 'sexual offences'. On the basis of these, Kerkhof (1982:27) counted in 1935:3, 1936:6, 1937:5, 1939:171, and in 1940:20 European men prosecuted for the offence of Article 292.

12 Handel in meisjes 1929; Onthullingen vrouwenhandel 1928; Politie en prostitutie 1917; Scherpere bestrijding prostitutie 1929; Stern 1927; Technische zaken 1926; Zedenpolitie Amsterdam 1925. The journal for the Association of Indonesian Policemen, Medan Polisi Boemipoetra, showed no special interest in this topic in the 1920s. 
during the vice scandal played a role as experts, wrote on related topics, for example on how to determine the age of a young men - which implied Indonesian men - or on how to interrogate youngsters (Adriaanse 1940; Müller 1941).

How, in the period before the 'vice scandal', police authorities in the Netherlands Indies dealt with possible homosexual relationships in the colonial police force is hard to find out and deserves further research. The weakness with which homosexuality was associated did not match the representation of the police as a tool of violence that was also the face of the colonial state. From the suggestive Lifebuoy advertisement mentioned above, the bodily training and gymnastics at the Police School, and the very fact that policing was male work, it may be inferred that it existed, or the possibility should not be discounted. A police recruit's diary from 1928 reveals that 'homosexuality' was a topic during a first-aid course for superintendents at the Police School in Sukabumi as a disease and thus probably as a warning too. The owner of the diary, a colonial soon-to-be superintendent of police as well as a Catholic butcher's son fresh from the Netherlands, was upset. He had never heard of such a thing, he wrote. His classmates appeared to have been full of this topic on the day, and he wondered 'how the world could be so wrong'. ${ }^{13}$

The policy towards homosexual police officers became clear enough during the vice scandal in 1938, in which at least four European police officers were arrested and interrogated as suspects. Three were found guilty. These weak spots, as they were regarded then, were inconspicuous within the massive number of other European homosexuals who were arrested, and in terms of the attention the press paid to the highest and most famous of them. For the police, the vice scandal would, on the contrary, turn out to be an event that not so much showed the weakness, but rather the strength and healthy morals of the police, and thereby of the state.

PURITY CRUSADE

The Netherlands Indies' vice scandal started in the heart of colonial civilization, the capital city, Batavia. It was there, in early 1937, that the Chief Superintendent of the Batavian city police, P. Dekker, for the first time had to give account to his superiors,

13 Diary of P. van der Poel, in: Nederlands Instituut voor Militaire Historie (Netherlands Institute for Military History), The Hague. 
the Resident of Batavia, and the new Governor-General A.W.L. Tjarda van Starkenborgh Stachouwer, for the police's policy towards homosexual vices in Batavia. The immediate occasion was a petition of the board of the Christelijke Staatspartij (CSP, Christian State Party) to the Governor-General in December 1936 in which it complained about the "rampant sin of homosexuality [...] among very well-known persons, men of good position in society'. The CSP-board admonished the Governor-General to make the police investigate the matter thoroughly - especially among the civil service - and report to the government so that it could take measures against this 'evil'. The police should not only act against those who committed the offence of having sexual relations with young men under age, but also against 'the evil' among grown-up men in general. ${ }^{14}$

The CSP-board justified its request on three grounds. One was the free local paper, De Ochtendpost (Morning News), that in its gossip column 'Batavian Nouvelles' informed its readers extensively about the way Batavian men (and women) of very good position spent their nightlife. Another one was an article in the police journal Het Politieblad (The Police Journal), entitled 'Ontucht en diefstal' (Vice and theft), from which the CSP-board concluded that there must be a connection between 'crime and the deviant $\sin { }^{15} \mathrm{~A}$ third factor was the rumour that the PPAA, the indigenous Association for the Suppression of Trade in Women and Children, was bracing itself to expose vice scandals. The CSP board concluded that 'European society could not stay behind'. ${ }^{16}$ Thus, worried about European sexual deviant vices, and facing initiatives of a purity crusade from indigenous society, the board of the CSP thought it was urgent to show that European society was not weakening, but strong.

In Batavia, the police authorities showed no worries at all when the Governor-General, via the Attorney General (in charge of central police), asked them for a reaction to the CSP's petition. Chief

14 Petition, Board of CSP, 8-12-1936, in: Nationaal Archief (NA), The Hague, Ministerie van Koloniën (Koloniën), Geheime Mailrapporten, serie AA, 1914-1952, nummer toegang 2.10.36.06, inventarisnummer (inv.nr) 144, Mailrapport (MR) 1937, 989+. See also Kerkhof 1982:32-6.

15 Ibidem. Unfortunately, I have not found either of the two articles mentioned in this letter (yet). Het Politieblad was the journal of the association for policemen of the lower intermediate ranks, the Algemeene Politiebond van Politiepersoneel in Nederlandsch-Indië (The General Police Association). Until 1931 it was known as the Association for Head Constables and Chief Inspectors in the Netherlands Indies.

16 Petition, Board of CSP, 8-12-1936, in: NA, Koloniën, Geheime Mailrapporten, 2.10.36.06, inv. nr 144, MR 1937, $989+$. 
Superintendent of Police P. Dekker conceded that the police kept a list of names, but a very unreliable one, not to be used, and secret. Although he referred to homosexuality as 'evil' he also, in a laconic way, pointed to the fact that the police could not act against homosexuals: not 'as long as an homosexual didn't interfere with men under age, violate public virtue, or commit crimes'. The Resident confirmed that there was no need to worry: so far there were no vice scandals in Batavia, and the police were watching. In his letter to the Governor-General, Attorney General G. Vonk also insisted that "the police in general should refrain from investigating an official, of whom it is only a surmise that he goes around with adults from the same sex, which is not a crime'. Neither rumours, nor conjectures, nor the unreliable name-list could serve an investigation against acts that were not liable to punishment. ${ }^{17}$

Thus, the CSP came away empty handed. It could not convince the police authorities in the Netherlands Indies of the relationship between homosexuality, crime and the weakening of public morals. The topic remained in the air, however, throughout 1937 and 1938. This was partly due to a more successful Christian lobby from the Netherlands where the government happened to sharpen legislation towards sexual vices $;^{18}$ and there was a minor homosexual vice scandal in Surabaya early in 1938, which became a favourite topic for further gossip and moral indignation in the Netherlands Indies newspapers. Continuing Christian lobbying in the Dutch Parliament resulted in the request of the Minister of Colonies, H. Colijn, to Governor-General Van Starkenborgh Stachouwer, to explain rumours about the increase of homosexuality in the Netherlands Indies, and the weakening of public morals in the colony. The Governor-General, again, denied there was a problem. Another reason for more attention for the topic - or more gossip - in the Netherlands Indies newspapers, enlivened by the minor vice scandal in Surabaya, was because of the obsessive indignation of one particular conservative newspaper-editor, H.C. Zentgraaff from the Javabode, with the free lifestyle of the group of Western artists, scientists and tourists that flocked to Bali in this period. In his eyes, they were vicious, exemplified by the eccentric German artist, Walter Spies, who also happened to be and act publicly homosexual. ${ }^{19}$

17 Resident of Batavia to Attorney General, 22-1-1937; Attorney General to Governor-General, 27-1-1937, in: NA, Koloniën, Geheime Mailrapporten, 2.10.36.06, inv. nr 144, MR 1937, 989+.

18 On this episode, see Koenders 1996:249-63.

19 See Zentgraaff looking back in the Javabode, 5-1-1939, quoted in Kerkhof 1982:59. 
A MORAL WINDFALL ON THE SUSPICIOUSNESS OF SWIMMING AND CYCLING IN SUKABUMI

In November 1938, the Batavian police were tipped off that a wellknown homosexual, staying at a hotel in Batavia, received underaged men in his hotel room. At that moment, in the climate of public moral indignation about homosexuality as a weakening vice, the police must have realised they had a good chance to perform as a successful civilizing force and ensure colonial decency - in short, to show that they were strong, and to show off colonial moral strength. Two weeks of observation were enough to confirm this tip and arrest the man, a certain W.G. van Eyndthoven, who had never made a secret of his being homosexual. ${ }^{20}$ The police only realized what a good prey they had, when they found in Van Eyndthoven's hotel room a huge collection of letters between Van Eyndthoven and homosexuals in the Netherlands and the Netherlands Indies. These letters seemed a windfall for successful moral policing. They were the basis of a secret police investigation, taking place in Batavia in the first two weeks of December 1938, into the nature and reach of a possible network of homosexuals in the Netherlands Indies. They therefore can help us to get an idea of police investigation methods into the vice scandal.

In two senses Van Eyndthoven's private correspondence formed a clue for the police investigation: first, the letters alerted police to their senders and to their male friends, who all became suspects because of their connection to Van Eyndthoven; and second, they provided insight into the jargon and vocabulary, the pet names and coded words that some authors used, and that, according to police suspicions, might reflect secret, deviant and even forbidden behaviour. Thus the police found out that Van Eyndthoven and some of his connections used the word 'onbetaalbaar' (priceless) to refer to 'bijzonder genotvolle belevenissen' (very pleasant experiences). ${ }^{21}$ This coded language was indeed part of the sub- or counter-culture, which homosexuals developed as a reaction to their exclusion, or to the fact that public opinion regarded their sexual preference as deviant (Kerkhof 1982:32-6). However, since the relationship between language and 'reality' is hard to coin in general, the police here went along a very slippery road of interpretation and proof

20 Attorney General Marcella to Governor-General Van Starkenborgh Stachouwer, 6-3-1939, in: NA, Koloniën, Geheim Archief, 1901-1940, nummer toegang 2.10.36.51, inv. nr 546, Verbaal 25-4-1939, E16; see also Koenders 1996:309.

21 Police interrogation G., procès-verbal, 1-12-1938, in: Arsip Nasional Republik Indonesia (ANRI), Jakarta, Archive of Binnenlands Bestuur (BB), 3409. 
finding. In this context anything could be meaningful and suspicious - such as an invitation to come for 'a fresh nose', a swim, and a bicycle ride in Sukabumi, which the police found among Van Eyndthoven's letters. Ironically, the unlucky sender was a young pupil of the police academy in Sukabumi. ${ }^{22}$

On 1 December 1938 the Superintendent of Batavia's police criminal investigation department, William Edward Böck, crossexamined recruit police officer H.A.I. Geraerts, the sender of the suspicious invitation. The two policemen met at the breeding place of the modern colonial police, the police academy in Sukabumi. Böck's first aim was to establish the nature of the connection between Geraerts and Van Eyndthoven (whom he had interrogated two days before) in order to get a further picture of the presumed homosexual network in the Netherlands Indies, and to figure out if Geraerts was gay. Therefore, Geraerts had to clarify all the names and pet names of homosexuals that the police had derived from Van Eyndthoven's letters. Geraerts cooperated as far as he could, admitted to having friendly relations with Van Eyndthoven, but denied being attracted to men or to have experienced gay sex. He maintained that his proposal to Van Eyndthoven to pass by for a swim and a bicycle ride was as innocent as possible. ${ }^{23}$ On the surface, his invitation fitted the clean and fresh hilly air of Sukabumi. Under the circumstances, appearances were against him. Geraerts seemed not only to have known Van Eyndthoven well; it was precisely the place where he had met Van Eyndthoven that made him even more suspicious: a certain private house in the colonial entrepreneurial town Medan (Sumatra).

Young, fresh and green, Geraerts arrived in the Netherlands Indies in November 1937 - most impressively by bicycle - together with a male companion, W.H.H. Peltzer, both in search of their fortune. The house in Medan was one of the first places they stayed in the Netherlands Indies. It was well known in Medan as a meeting place for homosexuals. Geraerts and Peltzer might have not been aware of that, but must have realized sooner or later. The European owner himself was gay; he lived with a young Indonesian man. They shared a bedroom. Now and then there were parties in the house, with men dancing together and kissing in public. Directed by Van Eyndthoven's private letters and with the help of their colleagues in Medan, the Batavian police knew the place by now. According to his letters, Van Eyndthoven had found this address via the Medan housing agency 'Homo-sex'. Van Eyndthoven was one of the ten- 
ants of the house during the time that Geraerts stayed there. It was then that they first met. Van Eyndthoven rented the pavilion in the garden. Peltzer and Geraerts, for reasons of economy, shared a room in the house, and thus slept in one space - like the European owner and his Indonesian friend did. For Böck, this was very suspicious. Geraerts had to draw for him how this male household in Medan, and especially the sleeping quarters, was organized. Wisely, Geraerts showed the two beds far apart in the room (Figure 6). ${ }^{24}$

Böck also paid special attention to the picture postcard Van Eyndthoven sent to Geraerts from Batavia the moment he heard that Geraerts had moved to Sukabumi and enrolled at the police academy. If he were ever in Batavia, so Eyndthoven typed on his typewriter, Geraerts should come over to dredge up memories of the good old days. 'Do you remember after that meeting? Priceless!' It was especially this last word, notably handwritten, as the police report remarked, that Böck wanted Geraerts to clarify. Geraerts recognized 'priceless' to be in Van Eyndthoven's hand, but pretended not to know its special meaning. For the moment Böck left it there, either giving Geraerts the benefit of the doubt, wishing to keep up the appearance of the police, or merely postponing the fate of this useful informant. ${ }^{25}$

In the meantime, the police collected new incriminating information against Geraerts through interrogations with the other, now publicly gay, inhabitants of the Medan house. On request, Oesman, the Indonesian partner of the house owner, denied that Geraerts was 'like the other men'. However, he also stated that Geraerts had kissed him once or twice during a party. During that interrogation Oesman also had to account for his desire for men. He felt like

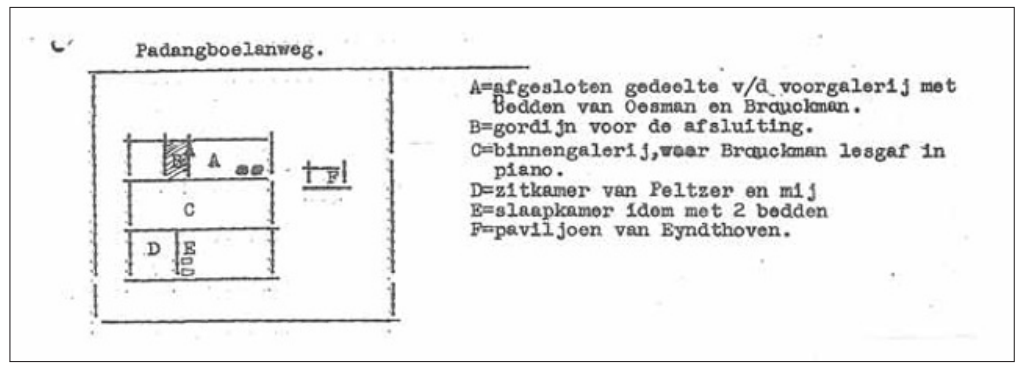

Figure 6. Drawing of how the male household in Medan was organized. Geraerts had to make this drawing during his interrogation in December 1938.

24 Police interrogation G., procès-verbal, 1-12-1938, in: ANRI, BB, 3409.

25 Police interrogation G., procès-verbal, 1-12-1938, in: ANRI, BB, 3409. 
a woman, Oesman explained to his interrogator, he longed to be a woman, and to be with a man. He never felt anything for girls. 'I only care to dance with men'. Geraerts often joined the parties at the house, Oesman continued, but he never danced; once Geraerts had tried to dance with Oesman, but Geraerts couldn't dance, according to Oesman. ${ }^{26}$ Two weeks later, the Batavian police subjected Geraerts to a second cross-examination, now at the Office of the Public Prosecutor in Batavia. Superintendent of Police J.C. Julianus, much more direct then Böck, asked Geraerts if he ever had been intimate with one or more persons in the circle of men frequenting the Medan house. Geraerts again maintained his innocence. He conceded that Oesman once kissed him on the cheek, and that he let that pass by. ${ }^{27}$

Presumably because most witnesses in Medan, like Oesman, stressed that Geraerts was not homosexual, the police let him go after this second interrogation. However, Geraerts remained stigmatized like the other victims of the police raids against homosexuals. He deserved the benefit of the doubt, as the interim Chief Superintendent of Batavia's police force admitted to the Head of the Police Department. The homosexual witnesses from Medan regarded Geraerts as 'somewhat naive', he explained, and they teased him, because he did not understand their hints and ambiguous wordplays. But they also stated that Geraerts kept aloof. There were, in short, no proofs that he was gay. ${ }^{28}$ Thus, Attorney General Marcella informed the Director of Interior Administration. But he added that the evidence of Geraerts's past in Medan, and his attitude during the interrogations, made him seem 'not particularly firm nor vigorous' in character. ${ }^{29}$ It was up to the Director of Interior Administration to decide if Geraerts was still fit for the colonial police force. Apparently he was, for Geraerts was allowed to stay. He finished the exams for the rank of head constable, graded number 10 out of 75 candidates, and left for a post in East Java. The Governor of East Java, however, received Geraerts's files. These included the verdict of the Head of the police academy, that Geraerts had 'certain qualities, which made him less fit for the police service'. ${ }^{30}$ Geraerts was clean, but was he strong?

26 Fragment of the interrogation of O., by the Public Prosecutor in Batavia, 30-12-1938, in: ANRI, BB, 3409.

27 Police interrogation G., procès-verbal, 7-1-1939, in: ANRI, BB, 3409.

28 Interim Chief Superintendent of the Batavia police force, to the Head of the Department of Police, 5-1-1939, in: ANRI, BB, 3409.

29 Attorney General to Director of Interior Administration, 7-1-1939, in: ANRI, BB, 3409.

30 Head of the police academy to Head of the Department of Police, 5-5-1939; Director of Interior Administration, 5-6-1939, in: ANRI, BB, 3409. 
The police interrogation of Geraerts suggests that the methods in this 'secret' police investigation hardly differed from those of the Netherlands Indies' political police and their hunt for communists since the repression of the communist revolts in 1926-1927. ${ }^{31}$ Like the political police, the Batavian special vice squad looked for keywords (in this case not pointing to communist ideology, but to homosexual jargon or coded homosexual language), connections (being befriended by Van Eyndthoven or known by him was enough reason to be suspected of deviancy), and organization. (All these clues together might indicate a criminal gang, which, in this case, traded young men under age, and which spread the weakening danger of homosexuality like a contagious disease).

BLAME AND SHAME

The secret investigation of course was not a secret anymore by midDecember, with names of the first victims published in the Netherlands Indies' newspapers - among them two well-known high officials. ${ }^{32}$ On the basis of the findings of the Batavian police, the new Attorney General H. Marcella concluded that 'the criminal homosexuality' was of such a large scale in the Netherlands Indies, that it needed 'serious attention and stout resistance'. Thus, right after Christmas, on 27 December 1938, Marcella ordered the colonial police, the colonial administration, and all the public prosecutors throughout the Netherlands Indies as a follow up to the Batavian police investigations against gay sexual offences, to act against all persons committing 'this evil', without discrimination (with emphasis). And thus begun the systematic police campaign against homosexuals, led by the indefatigable Public Prosecutor T.M. de la Parra: from Sabang to Merauke, and from school heads to the highest officials. ${ }^{33}$

Within the general state of moral indignation and public wondering that went along with the police raids, it was the arrest of the Resident of Batavia, H. Fievez de Malines van Ginkel - who happened to be head of the Batavian police - that came as the greatest shock to the public. It is very likely that many people knew

31 On the methods of political policing in the Netherlands Indies after the communist revolts, see Bloembergen 2009:247-97; Shiraishi 1997.

32 For a broad evaluation of the Netherlands Indies' and Dutch press on the vice scandal, see Kerkhof 1982:58-77.

33 Report Attorney General, 6-3-1939, in: NA, Koloniën, Geheim Archief, 2.10.36.51, inv. nr 546, Verbaal 25-4-1939, E16; see also Koenders 1996:329. 
the Resident was a frequent visitor of 'de baan' ('the lane'), or the area in Batavia where it was possible to pick up boys. Chief Superintendent Dekker himself most surely must have known. ${ }^{34}$ The Resident's confession, in January 1939, therefore implied corruption of the Batavian city police. Both the Resident and Dekker had to justify - again - police policy towards homosexual vices. How honest had they been, when they reacted to the CSP's petition of November 1936? The Resident, who turned completely grey within three months after his arrest, had to admit in a rather predictable hearing that he had endorsed a passive policy. ${ }^{35}$

Dekker, who at the time had only been chief superintendent in Batavia for half a year, claimed that he was afraid he would lose his job if he reported the Resident's personal conduct. He also explained the police's policy of tolerance towards homosexual vices by lack of personnel, and changes in personnel at the Batavian vice squad. Finally, the attitude of the former public prosecutor in Batavia, now temporarily replaced by De la Parra, had been, in his view, remarkably uncooperative in cases of occasional arrests of homosexuals. As a consequence, police subordinates concluded that they could refrain from arresting homosexual suspects, as long as they were not going around with under age European men. Attorney General Marcella confirmed Dekker's last remark: according to him it had been an unclear policy towards homosexuality that had blinded the police to the actual 'evil'. Dekker came away with a reprimand for keeping silent about the Resident. ${ }^{36}$

The police operations against homosexuals remind us of the mass arrests of alleged communists - which, however, only took place after the revolts of 1926-1927 - and were in methods very comparable to political police repression. Also, they provide us with one of the few examples of preventive policing - in this case against the phantom of weakening gay vices - that were successfully directed at central level. If it were up to De la Parra, this massive investigation also would have been proceeded in a uniform way:

34 It turned out that Dekker actually had seen a compromising police report on the Resident dating from July 1938. In this report two young homosexuals who were involved in the Surabayan vice scandal mentioned above had pointed to the house of the Resident of Batavia, as one of the addresses they used to visit. Dekker put the report aside. This was in line with the police policy, which he had defended at the end of 1937. Report Attorney General, 6-3-1939, in: NA, Koloniën, Geheim Archief, 2.10.36.51, inv. nr 546, Verbaal 25-4-1939, E16.

35 Fragment of the cross-examination of the Resident, by Public Prosecutor A. Mieremet, 19-11939, in: NA, Koloniën, Geheim Archief, 2.10.36.51, inv. nr 546, Verbaal 25-4-1939, E16. 'Suspect has turned completely gray' as the Bataviaasch Nieuwsblad, 24-4-1939 wrote in its report on the trial of the Resident in April 1939.

36 Attorney General to Resident of Batavia, 16-2-1939; report Attorney General, 6-3-1939, in: NA, Koloniën, Geheim Archief, 2.10.36.51, inv. nr 546, Verbaal 25-4-1939, E16. 
he himself travelled throughout Java to attend the hearings of suspects personally. However, at the local level not every head of police was as enthusiastic as De la Parra. The Resident of Banjumas, for example, when the public prosecutor of Semarang urged him to act against homosexuals, was not willing to cooperate since he had no wish to compromise persons of good reputation 'just like that' (Van Baal 1986). The Resident of Bali, on the other hand, apparently more willing to join this homophobic campaign than the Resident of Banjumas, reported that the police during their investigation lacked cooperation of the local population, who, in his view, were manipulated by the artistic Western troop in Bali. ${ }^{37}$ Elsewhere, in the main cities of Java, the police successfully enforced cooperation by one-day raids against street boys, who they arrested to act as witnesses. ${ }^{38}$ These uniform operations were not typical of the daily practice of civil or political policing. Apparently homosexuality was an easier adversary to imagine and coin, and thus bind the ethnically diverse colonial police, than 'nationalism' was.

The result was telling, as we already know. At least 223 men were taken in preventive detention (quite often for several months). By far most of them were European (among whom three policemen), but the list of detainees also counted nine Indonesians, and six representatives of other Asian population groups (one Armenian, four Chinese and one Arab). Most of these men were tried and sentenced to imprisonment, varying from periods of two months to two years. ${ }^{39}$ The indigenous street boys, acknowledged by the colonial authorities to be prostitutes and not homosexuals, were judged differently. Those who were above the minority age were sentenced to jail because of violating the ban on streetwalking. Those below the minority age were sent to the juvenile re-education facilities managed by Pro Juventute. ${ }^{40}$ Measures against high colonial officials, working at governmental departments in Batavia, seemed to have been decided at a faster speed. By March 1939 at least 50 gov-

37 Report Resident of Bali and Lombok, 2-3-1939, in: NA, Koloniën, Geheim Archief, 2.10.36.51, inv. nr 562, Verbaal 13-9-1939, Y36. On the ultimately rather successful hunt of homosexuals on Bali, see Kerkhof 1982:47-53.

38 In Batavia on 28 December; in Malang on 7 January 1938; in Bandung on 10 January; in Ceribon on 12 January. In Batavia the police again arrested, in one day, on 13 January, 36 persons among whom however only a few witnesses. Bataviaasch Nieuwsblad, 13-1-1939.

39 These figures are based on the list compiled by Kerkhof (1982:87-8, 108-14). Since this list merely shows initials of names, it is unclear how many Eurasian men were on it. It seems fair to conclude, however, that the raids were in the first instance directed against European men.

40 Kerkhof 1982:87. Koenders (1996:314) quotes W.J. de Haas, the Head of the Prison System in the Netherlands Indies, who asserted in May 1939, to a Dutch official, that these street boys were mainly motivated by money, and quite often supported by their families to engage in this business. A psychiatrist examined 34 of these boys and declared none to be homosexual. 
ernmental officials had been arrested and interrogated; 38 of them heard that they had to go, either because they were fired, dismissed or allowed to go 'on leave'. ${ }^{41}$ Attorney General Marcella, on request of Governor-General Van Starkenborgh Stachouwer, arranged a special measure for the dismissal of homosexual officials. Those who had only been arrested as homosexual suspects were either honourably discharged or transferred. Those who had committed paedophilia were dismissed from the service. In the future, new officials arriving from the Netherlands would need an official confirmation, stating they were not communist or 'like that' (Kerkhof 1982:43; Koenders 1996). Apart from the mass arrests and the many convictions, there were, possibly, three suicides.

A sour example of the harm this episode did to many individuals in the Netherlands Indies is the story of a well-qualified high governmental official, W.Ph. Coolhaas, who the police interrogated because of his homosexual inclinations. The government allowed Coolhaas to go on leave, but refused to take him back when his period of leave ended. After the war, Coolhaas re-applied - any job in the colonial administration would do - assuring the authorities that he had had himself cured by a Swiss psychiatrist in Zürich, pupil of the famous psychoanalyst Ernst Jung. Recently happily married, he thanked God that he was 'healed' by now and that he had found the right way in the field of sex. ${ }^{42} \mathrm{He}$ was strong again.

\section{TRANSNATIONAL SCANDALS?}

The Netherlands Indies' purification campaign did not stand on its own. Other, comparable homosexual scandals, resulting in similar police hunts of homosexuals took place in the 1930s in British Malaya, in the Netherlands, and in Nazi Germany. Interestingly, these scandals, although not all of the same size and scale, more or less developed in the same pattern. They all took place in a period of political and economic insecurity, and in societies marked by sharp political divisions. All the campaigns were initially directed against highly placed governmental or party officials. They started off with rumours about the homosexual behaviour of certain individuals, which were often (not always) supported by tangible evi-

41 Report Attorney General, 6-3-1939, in: NA, Koloniën, Geheim Archief, 2.10.36.51, inv. nr 546, Verbaal 25-4-1939, E16.

42 Coolhaas to General-Major Bongers, 23-5-1945, in: NA, Ministerie van Koloniën te Londen, 1940-1948, nummer toegang 2.10.45, inv. nr 1085. 
dence, such as a diary (in the case of British Malaya) or a collection of letters (in the case of the Netherlands Indies). This 'evidence' provided the police with generous source material, and a starting point to investigate a presumed larger 'network' of homosexual officials. Most of these cases caused a huge public scandal, which was widely and intensely covered by the local and national press. ${ }^{43}$

This common pattern in timing, context, focus and actions against homosexuals suggests that these anti-homosexual campaigns reflected a struggle over competence and power, more than filling a need to get rid of deviant sexual behaviour. This remains a matter of speculation, however. But this was a time in which certain groups in society felt the need for strong and clear leadership. Since public morals considered homosexuals to be weak in character, they could therefore, at this particular time, be thought unfit for the kind of authority that society and insecure times needed.

Especially remarkable seems to be the parallel in timing between the campaign in the Netherlands Indies with the Nazi campaign against homosexuals in Germany - here as enemies of the state - which started to be implemented systematically from 1936 onwards. There are, however, no direct connections, nor are there indications that members of the Nationaal-Socialistische Beweging (NSB, Dutch national socialist party) in the Netherlands Indies had anything to do with the campaign in the colony. On the contrary, some members of the NSB in the Netherlands Indies were homosexuals, as was also the case in the Netherlands. And to complicate matters: as a consequence of the fierce Nazi campaign against homosexuals in Germany, both communists and members of the NSB in the Netherlands, for propaganda reasons or for selfconfirmation, accused each other of incorporating homosexuals, therefore weakening their party (Koenders 1996:366-74).

But there was a Dutch connection to the Netherlands Indies anti-homosexual campaign. In its request of December 1936 the CSP, which was closely connected to the Dutch Anti-Revolutionaire Partij (ARP, Anti Revolutionary Party), may have been inspired by a huge homosexual vice scandal, the so-called 'Ries-affaire', which attracted public attention in the Netherlands from the second half of 1936 until early 1937. This Dutch scandal carried the same characteristics as the one in the Netherlands Indies: it began with the

43 On the scandal in British Malaya, and the circulating idea of the existence of a homosexual network in the colonial administration in the 1930s, see Aldrich 2003:194-8. On the scandal in the Netherlands (the so-called Ries Affaire in 1936-1937), and on the scandal in Germany (the Röhm Affaire in 1934) and its aftermath in the Netherlands, see Koenders 1996:295-303, 336-41. On the campaigns and scandals in Nazi Germany, see Micheler 2002. 
police arresting a highly placed governmental official, the Chief Treasurer L.A. Ries, and a number of his friends who were also high officials, for having committed homosexual offences. The arrest of Ries became a public scandal which resulted in a nasty discussion on the quality of the evidence in the Dutch parliament, and which attracted the warm attention of the public and Dutch national newspapers for several months. The Dutch Minister of Finance, in the end, was happy to fire his highest official, with an argument that would now sound very familiar: 'he was of a character and mind [...] because of which he lacks, outwardly and inwardly, the kind of authority we need. ${ }^{\prime 4}$ He was not strong enough.

\section{THE INDIES' SCANDAL: BEING CLEAN IS BEING STRONG}

In hindsight the massive hunt for homosexuals can be understood as an attempt of the colonial authorities to appear strong and virtuous. The attempt got out of hand, but it also fitted within the conservative politics of rust en orde, or the zaman normal of the 1930s. Finally, this purifying crusade was, however, force and violence out of weakness.

At the end of the 1930s, this fake and enforced atmosphere of normalcy was extremely tense in reality, reflecting the essential weakness of the colonial state. This state was threatened by the continuous challenge of Indonesian nationalism and by a new danger, the possibility of war in Europe and Asia. Against this background, the police raids against homosexuals can be understood as an endeavour of the colonial authorities to stay firm by showing firmness. By catching the elusive, the unfathomable, and the deviant as the weak spot, they emphasized the opposite: the male heterosexual strength of the colonial state. At the same time this moral cleansing was also meant to show the civilized face of the colonial state, and thus to legitimize colonial authority to appease possible indigenous critics. In that sense, the questions of the Indonesian nationalist chairman, Mohammad Husni Thamrin, in the Volksraad (People's Council) in Batavia, on 20 January 1939, about the worrying shape 'the perverse lechery' in Batavia took, were grist to the mill of those enthusiasts who wanted to continue the campaign against homosexuals as thoroughly as possible. ${ }^{45}$ In a double sense then, 'cleaning' society of homosexual vices meant showing that the colonial state was strong.

44 On this case, see Koenders 1996:295-306. The quotation of the Minister is on page 301.

45 Thamrin's speech was published - with approval - in the Bataviaasch Nieuwsblad, 21-1-1939. 
This mode of thinking made its way to society through a typical way of reasoning connected to the campaign.

Those who took part in this purifying crusade - police, colonial authorities, journalists and public (letter writers) - used the same kind of vocabulary; everybody played with the idea of cleanliness and (moral) hygiene. People were talking about cleaning, cleansing, and moral strength on the one hand, and, when it came to homosexual vices, about dirtiness, viciousness and weakness in character - with crime and evil as the ultimate dirt - on the other hand. The repression of homosexual vices, in the eyes of most commentators in the Netherlands Indies newspapers, apparently meant the restoration of colonial moral strength and honour. This way of talking and writing about the scandal implied a common notion that cleaning meant showing strength, and the apparent need for that.

The trigger of the campaign in the Netherlands Indies was the publicly expressed indignation of the CSP about homosexual vices in the colony, which was specifically directed against well-known Europeans of good, official position. As has been suggested by others before, this indignation might have been fed by the increasingly conservative climate in the Netherlands Indies, and by a growing sense of insecurity, due to fear of foreign invasion and of nationalist (or communist) opposition - which the Lifebuoy soap advertisement mentioned at the beginning of this chapter also suggested. If, in that context, homosexuality moreover was related to the weakening of public morals, then the cleansing of it could become an important means to show strength and capability. Being clean, in that sense, is being strong. For the police this meant: making clean is showing strength.

Then there was, finally, the moral benefits in this particular conservative and moral hygienic climate: the discovery of the homosexual correspondence of Van Eyndthoven in Batavia, which could guarantee a successful performance of policing colonial decency, or civilization through policing. This, apparently, was especially attractive for the ambitious Public Prosecutor De la Parra, who came to Batavia only as a temporary replacement of his predecessor. The new, rather conservative Attorney General Marcella might also have been interested in an easy prey to impress his superiors (Kerkhof 1992:103). However, rumours, with the accompanying half information, suggest that not he, but Governor-General Van Starkenborgh Stachouwer - also rather conservative and relatively new - was actually the director behind the scenes for reasons of family affairs (Van Baal n.y.:329). Considering the Netherlands Indies' climate of gossip, it is hard to know the truth on this matter. However, as they were in charge of central police control, both of them were responsible. 
Perhaps, in the last instance, it was not really about cleanliness, but a combination of the right climate, an easy prey, and, last but not least, ambitions that provided the basis for the suddenly overactive police operations against homosexuals in the Netherlands Indies. But this would still mean that the whole cleansing process was meant to show that being clean is being strong.

\section{REFERENCES}

\section{Unpublished sources}

Arsip Nasional Republik Indonesia, Jakarta

Archive of Binnenlands Bestuur

Nationaal Archief, The Hague

Ministerie van Koloniën, Geheime Mailrapporten, serie AA, 1914-1952, nummer toegang 2.10.36.06

Ministerie van Koloniën, Geheim Archief, 1901-1940, nummer toegang 2.10.36.51

Nederlands Instituut voor Militaire Historie, The Hague

Diary of P. van der Poel

Published sources

Abalahin, Andrew Jimenez

$2003 \quad$ Prostitution and the project of modernity; A comparative study of colonial Indonesia and the Philippines, 1850-1940. PhD thesis, Cornell University, Ithaca, NY.

Adriaanse, P.M.

1940 'Het verhoor van kinderen in zedenzaken', De Politie 23:280-1. Aldrich, Robert

2003 Colonialism and homosexuality. Londen: Routledge.

Baal, J. van

[1986] Ontglipt verleden; Verhaal van mijn jaren in een wereld die voorbijging. Deel 1: Tot 1947; Indisch bestuursambtenaar in vrede en oorlog. Franeker: Wever.

Bloembergen, Marieke

2006 'Koloniale staat, politiestaat? Politieke politie en het rode fantoom in Nederlands-Indië, 1918-1927', Leidschrift 21-2:69-90. 
2007

'The dirty work of empire; Modern policing and public order in Surabaya, 1911-1919', Indonesia 83:119-50.

2009 De geschiedenis van de politie in Nederlands-Indië; Uit zorg en angst. Amsterdam: Boom, Leiden: KITLV Uitgeverij.

Dekker, P. and S.H. Tacoma

1938 De politie in Nederlandsch-Indië; Hare beknopte geschiedenis, haar taak, haar bevoegdheid, organisatie en optreden. Tweede herziene druk. Soekaboemi: Insulinde. [First edition 1929.]

Dirks, Annelieke

2011 For the youth and the future; Juvenile delinquency, colonial civil society and the late colonial state in the Netherlands Indies, 19001942. PhD thesis, Leiden University.

Hadler, Jeffrey

2008 Muslims and matriarchs; Cultural resilience in Indonesia through jihad and colonialism. Ithaca, NY: Cornell University Press.

Handel in meisjes

1929

'Handel in meisjes', De Nederlandsch-Indische Politiegids 13:47-8. Idenburg, P.J.A.

1961

'Het Nederlandsche antwoord op het Indonesische nationalisme', in: H. Baudet and I.J. Brugmans (eds), Balans van beleid; Terugblik op de laatste halve eeuw NederlandschIndië, pp. 121-51. Assen: Van Gorcum. [Ons XXste eeuwse Verleden, in Memoires en Biografieën 3.]

Kerkhof, Gosse

1982

'Het Indische zedenschandaal: een koloniaal incident'. MA thesis, Universiteit van Amsterdam.

1992 'Het Indische zedenschandaal: een koloniaal incident', in: Raymond Feddema (ed.), Wat beweegt de bamboe? Geschiedenissen in Zuidoost Azië, pp. 93-118. Amsterdam: Spinhuis.

Koenders, Pieter

1996 Tussen christelijk réveil en seksuele revolutie; Bestrijding van zedeloosheid met de nadruk op repressie van homoseksualiteit. $\mathrm{PhD}$ thesis, Rijksuniversiteit Leiden.

Micheler, Stefan

2002

'Homophobic propaganda and the denunciation of samesex-desiring men under national socialism', Journal of the History of Sexuality 11-1/2:95-130.

Müller, J.

1941

'Het onderzoek van misdrijven tegen de zeden verband houdende met het geslachtsleven', De Politie 14:477-82. 
Onthullingen vrouwenhandel

1928 'Nieuwe onthullingen over vrouwenhandel', De NederlandschIndische Politiegids 12:38-9.

Poeze, Harry A.

1994 'Political intelligence in the Netherlands Indies', in: Robert Cribb (ed.), The late colonial state in Indonesia; Political and economic foundations of the Netherlands Indies, 1880-1942, pp. 229-46. Leiden: KITLV Press. [Verhandelingen 163.]

Politie en prostitutie

1917 'De politie en de prostitutie', De Nederlandsch-Indische Politiegids 1:8.

Scherpere bestrijding prostitutie

1929 'Is scherpere bestrijding der prostitutie gewenst?', De Nederlandsch-Indische Politiegids 13:56-9.

Shiraishi, Takashi

1997

'Policing the phantom underground', Indonesia 63:1-46.

Stern, W.

1927

'Jeugdige getuigen bij misdrijven tegen de zeden', De Nederlandsch-Indische Politiegids 11:173.

Technische zaken

1926 'Technische zaken; De lotgevallen van meisjes, die op jeugdigen leeftijd zijn aangerand', De Nederlandsch-Indische Politiegids 10:136-7.

Thaib, Maisir

[1939] Bahaja homo-sexualiteit dan bagaimana membasminja. Fort de Kock: Djambek.

Zedenpolitie Amsterdam

1925 'Zedenpolitie te Amsterdam', De Nederlandsch-Indische Politiegids 8:307-9.

Zedenpolitie Batavia

1925 'Eene speciale afdeeling zedenpolitie voor Batavia', Orgaan van den Bond voor Ondercommissarissen en Politieopzieners in Nederlandsch-Indië9:47-51.

1926

'Eene speciale afdeeling zedenpolitie voor Batavia', Orgaan van den Bond voor Ondercommissarissen en Politieopzieners in Nederlandsch-Indië 10:78-83. 